\title{
Recent Progress on the Electrochemical Biosensing of Escherichia coli O157:H7: Material and Methods Overview
}

\author{
Nasrin Razmi ${ }^{1, * \mathbb{D}}$, Mohammad Hasanzadeh ${ }^{2}$, Magnus Willander ${ }^{1, *}$ and Omer Nur ${ }^{1}$ (D) \\ 1 Physics and Electronics, Department of Sciences and Technology, Linköping University, \\ SE-601 74 Norrköping, Sweden; omer.nour@liu.se \\ 2 Pharmaceutical Analysis Research Center, Tabriz University of Medical Sciences, Tabriz 51664, Iran; \\ mhasanzadeh2@gmail.com \\ * Correspondence: nasrin.razmi@liu.se (N.R.); magnus.willander@liu.se (M.W.)
}

Received: 3 April 2020; Accepted: 13 May 2020; Published: 18 May 2020

\begin{abstract}
Escherichia coli O157:H7 (E. coli O157:H7) is a pathogenic strain of Escherichia coli which has issued as a public health threat because of fatal contamination of food and water. Therefore, accurate detection of pathogenic E. coli is important in environmental and food quality monitoring. In spite of their advantages and high acceptance, culture-based methods, enzyme-linked immunosorbent assays (ELISAs), polymerase chain reaction (PCR), flow cytometry, ATP bioluminescence, and solid-phase cytometry have various drawbacks, including being time-consuming, requiring trained technicians and/or specific equipment, and producing biological waste. Therefore, there is necessity for affordable, rapid, and simple approaches. Electrochemical biosensors have shown great promise for rapid foodand water-borne pathogen detection. Over the last decade, various attempts have been made to develop techniques for the rapid quantification of E. coli O157:H7. This review covers the importance of E. coli O157:H7 and recent progress (from 2015 to 2020) in the development of the sensitivity and selectivity of electrochemical sensors developed for E. coli O157:H7 using different nanomaterials, labels, and electrochemical transducers.
\end{abstract}

Keywords: E. coli O157:H7; electrochemical biosensors; biomedical analysis; environmental monitoring; portable biodevice; biotechnology

\section{Introduction}

The rapid spread of pathogenic bacteria, as well as their rapid development of antibiotic resistance, has caused worldwide concern as they are a major source of both foodborne and waterborne illnesses [1-3]. Pathogenic strains of bacteria are the main concern for environmental biology, hospitals, water supplies, and the food industry because of the diverse illnesses that microbial infection can cause, some of which can lead to death [4]. Contamination of food resources has led to the occurrence of certain diseases, placing a heavy responsibility on food distributors to restrict outbreaks $[2,5,6]$. More important, the majority of water sources are contaminated with pathogenic bacterial strains, such as Salmonella, Staphylococcus, and Escherichia coli, resulting in typhoid fever, gastroenteritis, cholera, and several diarrheal responses $[2,7,8]$. According to the 2016 report of the World Health Organization (WHO), 829,000 annual deaths from diarrhea occurred due to bacterial water contamination [9]. Around 600 million-nearly 1 in 10 people in the world-become ill due to the consumption of contaminated food, resulting in 420,000 deaths every year and the loss of 33 million healthy life years (disability adjusted life years; DALYs) [10]. E. coli is a fecal coliform bacterium found in the human gut and other warm blooded animals, and is typically harmless to humans [1,11]. However, pathogenic groups of E. coli strains can cause diarrheal illnesses. Pathogenic E.coli can be categorized into six groups, 
including diffusely adherent E. coli (DAEC), enterohemorrhagic E. coli (EHEC), enteroaggregative E. coli (EAEC), enteropathogenic E. coli (EPEC), enteroinvasive E. coli (EIEC), and enterotoxigenic E. coli (ETEC) [12-16]. One of the most important EHEC pathogens is E. coli O157:H7 due to its ability to cause bloody diarrhea, leading to potentially fatal hemolytic uremic syndrome (HUS). The O157:H7 serotype is one of the Shiga-toxin-producing E. coli (STEC) strains and causes worldwide infections [16]. Since its discovery in 1982, E. coli O157:H7 has appeared as an significant enteric, extremely infective water- and food-borne pathogen presenting a massive challenge to public health and financial stability in terms of medical cost [17]. The transmission of E. coli O157:H7 mostly occurs through the consumption of food, vegetables, milk, meat, and water sources that have come in contact with fecal matter at any point [2,18-20]. The ingestion dose of 10-100 cells of E. coli O157:H7 [21] can cause respiratory failure [22,23], seizures [24,25], gastrointestinal illness, renal failure, anemia [26], HUS, hemorrhagic colitis, as well as acute kidney failure and, finally, death, particularly in infants and immunocompromised individuals $[1,5,8,27,28]$. Therefore, a rapid, selective, sensitive, simple, accurate, and easy-to-use method for the determination and quantification of E. coli O157:H7 is an urgent task in the fields of environmental monitoring, clinical diagnosis, and food safety. Traditional methods for bacterial detection via standard microbiological approaches, including pre-enrichment, selective enrichment, biochemical screening, serological confirmation, and toxin testing, are time consuming (requiring 2-6 days for the result and confirmation), laborious, and vague in terms of results [20,29-31]. Plate culture, polymerase chain reaction (PCR), and enzyme-linked immunosorbent assay (ELISA) are currently the typically used detection methods for E. coli 0157:H7 [32,33]. The conventional plate culture method requires laborious procedures that require a relatively long time to get the result. Based on specific PCR variation, the detection time could take 5-25 h. Although PCR methods, mainly real time PCR, have been vastly used for E. coli O 157:H7 identification by targeting some virulence factor-encoding genes, it has disadvantages, including that most of the genes are not specific for this bacterium, and difficulty in differentiating between viable and nonviable cells. In addition, this method needs specific instrumentation and is time-consuming and complicated $[30,33,34]$. ELISA is an immunological technique which employs an enzyme for the detection of an antigen or antibody as a result of microbial presence in a sample. These techniques often require enrichment or purification steps and pretreatments, lengthening the analysis time. To overcome these drawbacks, effort has gone into the development of a rapid, sensitive, selective, and simple pathogen detection approach that provides accurate detection. For rapid detection methods, a lot of effort has focused on the improvement of reliability, specificity, feasibility in various environments, speed, cost, and miniaturization $[16,35]$. Recently, biosensors have become a more sensible option for the detection of E. coli O157:H7, as they are highly rapid, sensitive, selective, and provide accurate identification and quantification. Biosensors are defined as analytical devices using biological/biochemical reactions for detection of target analytes, and essentially consist of a bio-element and a transducer [36-39]. A biosensor should be able to give quantitative or semiquantitative information and detect the target molecule without requiring any additional processing steps. The measurement approach could be simply in a droplet format or in a continuous flow format. The performance of an ideal biosensor for pathogenic bacteria detection is summarized in Table 1 [40]. Biosensors have the advantages of simplicity, specificity, low detection limit, simple operation, being inexpensive, easy to use, providing real-time measurement, capability of multitarget testing and automation, portability, miniaturization, and rapid detection. In recent years, biosensors with different transducers have been extensively applied for pathogenic bacteria detection. Among the different types of transducers, electrochemical biosensors have gained more attention due to their simplicity and sensitivity. This review gives a general overview of the reported electrochemical methods from 2015 to 2020 for the rapid detection of E. coli O157:H7. 
Table 1. Summary of the requirements for a bacterial biosensor.

\begin{tabular}{cl}
\hline Feature & \multicolumn{1}{c}{ Requirement } \\
\hline Sensitivity & A biosensor should have the ability to detect the pathogen at very low infective dosage \\
\hline Specificity & $\begin{array}{l}\text { A biosensor should be able to discriminate between the target molecule and } \\
\text { nontarget molecules }\end{array}$ \\
\hline Robustness (durability) & $\begin{array}{l}\text { A biosensor should have the ability to withstand different conditions, such as changes } \\
\text { in temperature, etc. }\end{array}$ \\
\hline Detection time & Analysis time should be minimal for real-time response \\
\hline Reproducibility & The result should be reproducible over the period of time without failure \\
\hline Ease of use & The biosensor should not require specific operator skills \\
\hline Accuracy & A biosensor should not have should not have false-negative or false-positive results \\
\hline Cost-effectiveness & The biosensor should be inexpensive \\
\hline
\end{tabular}

\section{Electrochemical Biosensors for the Detection of E. coli O157:H7}

Electrochemical biosensors are frequently designed and have been widely used for the detection of food-borne and water-borne pathogens due to the possibility of miniaturization and construction of disposable, flexible, and cheap sensing systems. As reported by the International Union of Pure and Applied Chemistry (IUPAC), an electrochemical biosensor is an independently integrated system using a bioreceptor in contact with an electrochemical transduction part that provides specific quantitative or semiquantitative analytical data [41,42]. The current produced by oxidation and reduction reactions related to the presence of the electroactive species or its rate of production/consumption is measured by an electrochemical biosensor. The produced electrical signal is proportional to the target's concentration $[43,44]$. Electrochemical biosensors are categorized into four classes: impedance, amperometric, conductometric, and potentiometric, according to the nature of the electrochemical changes detected via the biorecognition reaction [38]. Simplicity and speed are the key advantages of electrochemical biosensors. Low-cost electrodes incorporated with simple electronics allow rapid detection in easy-to-use, miniaturized portable devices. For environmental monitoring, the capability to detect the target concentration within a complex sample at the point-of-care and in real time is particularly interesting $[38,45]$. The number of papers reported for the detection of E. coli O157:H7 using an electrochemical transducer from 2015 to 2020 is large. Table 2 summarizes the studies related to using an electrochemical transducer for the detection of E. coli O157:H7. As shown in Table 2, many of the studies are devoted to genosensors and immunosensors. Genosensors use DNA sequencing analysis for bacterial detection. Nucleic acid hybridization is based on the immobilization of a single-stranded DNA sequence on a specific substrate. An obtained electrical current signal is the result of the binding of a complementary DNA sequence to the probe DNA. Detection of a specific DNA sequence provides a rapid, simple, cost-effective, and physically small assay that can be operated by nonprofessional users [46,47]. Electrochemical immunosensors rely on an electrochemical signal resulting from stable antigen-antibody complex formation, allowing highly sensitive detection. A label or marker attached to an antibody $(\mathrm{Ab})$ or an antigen $(\mathrm{Ag})$ is required for labeled electrochemical immunosensors to achieve electron transfer. The detected amount of the label corresponds to the target analyte's concentration. In sandwich-based immunosensors, two specific antibodies are used to capture the target cell. One of the antibodies is immobilized on the surface of the electrode and the other one is labeled with an electroactive marker or a label which can produce an electroactive product [48,49]. For detection of pathogenic bacteria, different kinds of nanomaterials have been integrated into the biosensors, yielding improvements in terms of stability, sensitivity, selectivity, and speed of the electrochemical biosensors. As shown in Table 2, gold nanoparticles and nanostructures have gained considerable attention for the detection of $E$. coli O157:H7. Providing a stable biomolecule immobilization while retaining their bioactivity is the major advantage of using gold nanoparticles in electrochemical biosensors. Application of gold nanomaterials in an electrochemical biosensor offers improvements in signal amplification, electron transfer, and electrocatalytic activity. The unique properties of gold nanoparticles, including their inert nature in 
biological fluids, biocompatibility, presence of functional groups for binding ligands, high surface to volume ratio, etc., make their use promising in the construction of electrochemical biosensors [50]. In this review, an attempt has been made to organize the recently reported studies using electrochemical transducers (Table 2) for the detection of E. coli O 157:H7. The current challenges and future directions are discussed.

Table 2. Electrochemical sensors for E. coli O157:H7 detection.

\begin{tabular}{|c|c|c|c|c|c|c|}
\hline Method & Assay Strategy & Material Type & Technique & LOD & $\begin{array}{l}\text { Linear } \\
\text { Range }\end{array}$ & Ref. \\
\hline Voltammetric & Immunosensor & $\mathrm{Au}$ NPs & SWV & $10 \mathrm{CFU} / \mathrm{mL}$ & $\begin{array}{c}10-10^{6} \\
\mathrm{CFU} / \mathrm{mL}\end{array}$ & [51] \\
\hline Voltammetric & Aptasensor & - & DPV & $80 \mathrm{CFU} / \mathrm{mL}$ & $\begin{array}{c}5 \times 10^{2}-5 \times \\
10^{7} \mathrm{CFU} / \mathrm{mL}\end{array}$ & [34] \\
\hline Voltammetric & Aptasensor & $\begin{array}{l}\text { Single wall carbon } \\
\text { nanotube }\end{array}$ & CV-DPV & $1.7 \times 10 \mathrm{CFU} / \mathrm{mL}$ & $\begin{array}{c}1.7 \times 10-1.1 \\
\times 10^{7} \\
\mathrm{CFU} / \mathrm{mL}\end{array}$ & [52] \\
\hline Voltammetric & Immunoassay & SG-PEDOT-Au NPs & DPV & $3.4 \times 10 \mathrm{CFU} / \mathrm{mL}$ & $\begin{array}{c}7.8 \times 10-7.8 \\
\times 10^{6} \\
\mathrm{CFU} / \mathrm{mL}\end{array}$ & [53] \\
\hline Voltammetric & Genosensor & $\begin{array}{c}\text { Graphene } \\
\text { oxide-nickel } \\
\text { ferrite-chitosan } \\
\text { (GO/NiF/ch) film }\end{array}$ & DPV & $1 \times 10^{-16} \mathrm{M}$ & $\begin{array}{c}10^{-6}-10^{-16} \\
\mathrm{M}\end{array}$ & [54] \\
\hline Voltammetric & $\begin{array}{l}\text { Bare Indium Tin } \\
\text { Oxide (ITO) based } \\
\text { Immunosensor }\end{array}$ & Au NPs & DPV & 330 cells/mL & $\begin{array}{c}1-10^{6} \\
\text { cells/mL }\end{array}$ & [55] \\
\hline Voltammetric & Aptasensor & $\begin{array}{l}\mathrm{Cu}-\mathrm{MOF} / \mathrm{PANIAg} \\
\text { NPs }\end{array}$ & DPV-EIS-CV & $2 \mathrm{CFU} / \mathrm{mL}$ & $\begin{array}{c}2.1 \times 10^{1}-2.1 \\
\times 10^{7} \\
\mathrm{CFU} / \mathrm{mL}\end{array}$ & [56] \\
\hline Voltammetric & $\begin{array}{c}\text { Dual signal } \\
\text { amplification strategy } \\
\text { based on double DNA } \\
\text { hybridization }\end{array}$ & $\begin{array}{l}\text { Polyaniline film and } \\
\text { Au NPs }\end{array}$ & $\mathrm{CV}$ & $4 \mathrm{CFU} / \mathrm{mL}$ & $\begin{array}{l}4 \times 10^{6}-4 \\
\mathrm{CFU} / \mathrm{mL}\end{array}$ & {$[57]$} \\
\hline Voltammetric & Immunosensor & $\begin{array}{l}\text { Reduced graphene } \\
\text { oxide (rGO) }\end{array}$ & LSV-EIS & $4 \mathrm{CFU} / \mathrm{mL}$ & $\begin{array}{l}4 \times 10^{8}-4 \\
\mathrm{CFU} / \mathrm{mL}\end{array}$ & {$[58]$} \\
\hline Voltammetric & $\begin{array}{l}\text { Sandwich type } \\
\text { immunosensor }\end{array}$ & $\begin{array}{l}\text { Cadmium Sulfide } \\
\text { quantum dots in } \\
\text { zeolitic imidazolate } \\
\text { framework } \\
\text { (CdS@ZIF-8) } \\
\text { nanoparticles }\end{array}$ & DPV & $3 \mathrm{CFU} / \mathrm{mL}$ & $\begin{array}{c}10-10^{8} \\
\mathrm{CFU} / \mathrm{mL}\end{array}$ & [59] \\
\hline Voltammetric & $\begin{array}{c}\text { Multiple amplification } \\
\text { strategy via 3D DNA } \\
\text { walker }\end{array}$ & AU NPs & CV-EIS-DPV & $7 \mathrm{CFU} / \mathrm{mL}$ & $\begin{array}{c}10-10^{4} \\
\mathrm{CFU} / \mathrm{mL}\end{array}$ & {$[60]$} \\
\hline Impedimetric & $\begin{array}{l}\text { Interdigitated label } \\
\text { free microelectrode }\end{array}$ & - & EIS & 7 cells/mL & $\begin{array}{c}7.2 \times 10^{0}-7.2 \\
\times 10^{8} \\
\text { cells } / \mathrm{mL}\end{array}$ & [6] \\
\hline Impedimetric & Immunosensor & $\begin{array}{l}\text { Streptavidin coated } \\
\text { magnetic beads (MBs) }\end{array}$ & EIS & $10^{3} \mathrm{CFU} / \mathrm{mL}$ & $\begin{array}{l}10^{2}-10^{6} \\
\mathrm{CFU} / \mathrm{mL}\end{array}$ & [61] \\
\hline Impedimetric & $\begin{array}{l}\text { Label free ITO based } \\
\text { immunosensor }\end{array}$ & - & EIS & $1 \mathrm{CFU} / \mathrm{mL}$ & $\begin{array}{c}10-10^{6} \\
\mathrm{CFU} / \mathrm{mL}\end{array}$ & [62] \\
\hline Impedimetric & $\begin{array}{l}\text { Lectin functionalized } \\
\text { mixed self-assembled } \\
\text { monolayer }\end{array}$ & $\begin{array}{c}11- \\
\text { mercaptoundecanoic } \\
\text { acid (MUA) and } \\
\text { dithiothreitol (DTT) }\end{array}$ & EIS-CV & 75 cells/mL & $\begin{array}{c}1 \times 10^{2}-1 \times \\
10^{5} \text { cells } / \mathrm{mL}\end{array}$ & [29] \\
\hline Impedimetric & Immunosensor & $\begin{array}{l}\text { Graphene wrapped } \\
\text { copper (II) assisted } \\
\text { cysteine hierarchical } \\
\text { structure }\end{array}$ & EIS & 3.8 CFU/mL & $\begin{array}{c}10-10^{8} \\
\mathrm{CFU} / \mathrm{mL}\end{array}$ & [63] \\
\hline Impedimetric & $\begin{array}{l}\text { Aptasensor based on } \\
\text { Urease catalysis } \\
\text { amplification strategy }\end{array}$ & $\begin{array}{l}\text { Streptavidin modified } \\
\text { magnetic } \\
\text { nanoparticles, Gold } \\
\text { NPs }\end{array}$ & EIS & $12 \mathrm{CFU} / \mathrm{mL}$ & $\begin{array}{c}10-10^{5} \\
\mathrm{CFU} / \mathrm{mL}\end{array}$ & [64] \\
\hline
\end{tabular}


Table 2. Cont.

\begin{tabular}{|c|c|c|c|c|c|c|}
\hline Method & Assay Strategy & Material Type & Technique & LOD & $\begin{array}{l}\text { Linear } \\
\text { Range }\end{array}$ & Ref. \\
\hline Impedimetric & $\begin{array}{l}\text { self-assembled } \\
\text { monolayer based } \\
\text { immunoassay }\end{array}$ & - & EIS & $1 \times 10^{2} \mathrm{CFU} / \mathrm{mL}$ & $\begin{array}{l}10^{2}-10^{7} \\
\mathrm{CFU} / \mathrm{mL}\end{array}$ & [65] \\
\hline Impedimetric & $\begin{array}{l}\text { Ab based magneto } \\
\text { impedance sensor }\end{array}$ & Gold nanofilm & - & $50 \mathrm{CFU} / \mathrm{mL}$ & $\begin{array}{c}50-500 \\
\mathrm{CFU} / \mathrm{mL}\end{array}$ & [66] \\
\hline Impedimetric & $\begin{array}{c}\text { Multiple } \\
\text { interdigitated } \\
\text { electrode array }\end{array}$ & Gold thin film & IS & $39 \mathrm{CFU} / \mathrm{mL}$ & - & [67] \\
\hline Impedimetric & $\begin{array}{l}\text { Microelectromechanical } \\
\text { system (MEMS) } \\
\text { biosensor based on } \mathrm{Ab}\end{array}$ & Gold thin film & IS & $13 \mathrm{CFU} / \mathrm{ML}$ & - & [68] \\
\hline Impedimetric & Immunosensor & Magnetic nanobeads & - & $10^{4.45} \mathrm{CFU} / \mathrm{mL}$ & $\begin{array}{l}10^{4}-10^{7} \\
\mathrm{CFU} / \mathrm{mL}\end{array}$ & [69] \\
\hline Impedimetric & Immunosensor & $\mathrm{Cu}_{3}(\mathrm{BTC})_{2} / \mathrm{PANI}$ & EIS & $2 \mathrm{CFU} / \mathrm{mL}$ & $\begin{array}{l}2-2 \times 10^{8} \\
\mathrm{CFU} / \mathrm{mL}\end{array}$ & {$[70]$} \\
\hline Impedimetric & Aptasensor & $\begin{array}{l}\text { streptavidin modified } \\
\text { MNPs, Au NPs }\end{array}$ & EIS & $10 \mathrm{CFU} / \mathrm{mL}$ & $\begin{array}{c}10-10^{4} \\
\mathrm{CFU} / \mathrm{mL}\end{array}$ & [71] \\
\hline Impedimetric & Immunosensor & Au NPs & IS & $100 \mathrm{CFU} / \mathrm{mL}$ & $\begin{array}{l}300-10^{5} \\
\mathrm{CFU} / \mathrm{mL}\end{array}$ & [26] \\
\hline Impedimetric & DNA sensor & $\begin{array}{l}\text { 3-Aminipropyl } \\
\text { trimethoxysilane } \\
\text { (APTES) and GA }\end{array}$ & EIS & $0.5-25 \mathrm{pg} / 10 \mathrm{~mL}$ & $0.1 \mathrm{pg} / 10 \mathrm{~mL}$ & {$[72]$} \\
\hline Impedimetric & Immunosensor & Gold print & EIS & $3 \times 10 \mathrm{CFU} / \mathrm{mL}$ & $\begin{array}{c}10-10^{8} \\
\mathrm{CFU} / \mathrm{mL}\end{array}$ & [73] \\
\hline Impedimetric & DNA biosensor & $\begin{array}{l}\text { Graphene oxide } \\
\text { Chitosan Hybrid } \\
\text { nanocomposite }\end{array}$ & CV-EIS & $3.584 \times 10^{-15} \mathrm{M}$ & $\begin{array}{c}1 \times 10^{-14}-1 \\
\times 10^{-8} \mathrm{M}\end{array}$ & [74] \\
\hline Amperometric & $\begin{array}{l}\text { Hydrogen evolution } \\
\text { reaction based } \\
\text { immunosensor }\end{array}$ & $\mathrm{Au}$ NPs & CV-CA & $309 \mathrm{CFU} / \mathrm{mL}$ & $\begin{array}{l}10^{2}-10^{5} \\
\text { CFU/mL }\end{array}$ & {$[75]$} \\
\hline Amperometric & $\begin{array}{l}\text { Personal Glucometer } \\
\text { (PGM) Immunoassay }\end{array}$ & $\begin{array}{c}\mathrm{Au} @ \mathrm{Pt} / \mathrm{SiO}_{2} \mathrm{NPsand} \\
\mathrm{Fe}_{3} \mathrm{O}_{4} @ \mathrm{SiO}_{2} \mathrm{NPs}\end{array}$ & - & $\begin{array}{c}1.83 \times 10^{2} \\
\mathrm{CFU} / \mathrm{mL}\end{array}$ & $\begin{array}{c}3.5 \times 10^{2}-3.5 \\
\times 10^{8} \\
\mathrm{CFU} / \mathrm{mL}\end{array}$ & [76] \\
\hline Amperometric & Immunosensor & $\begin{array}{l}\text { PPy/AuNP/MWCNT/Chi } \\
\text { bionanocomposite }\end{array}$ & $\mathrm{CV}$ & $30 \mathrm{CFU} / \mathrm{mL}$ & $\begin{array}{c}3 \times 10-3 \times \\
10^{7} \mathrm{CFU} / \mathrm{mL}\end{array}$ & [77] \\
\hline Amperometric & DNA biosensor & $\begin{array}{c}\mathrm{GOx}-\mathrm{Thi}-\mathrm{Au} @ \mathrm{SiO}_{2} \\
\text { nanocomposites }\end{array}$ & CV-DPV & $0.01 \mathrm{nM}$ & $\begin{array}{c}0.02-50 \\
\mathrm{nM} / \mathrm{L}\end{array}$ & [78] \\
\hline Amperometric & $\begin{array}{l}\text { Nonenzymatic } \\
\text { immunoassay }\end{array}$ & $\begin{array}{c}\text { Silica coated } \mathrm{Fe}_{3} \mathrm{O}_{4} \\
\text { magnetic } \\
\text { nanoparticles and } \\
\mathrm{Au@Pt} \mathrm{nanoparticles}\end{array}$ & $\mathrm{CV}$ & $\begin{array}{l}4.5 \times 10^{2} \\
\mathrm{CFU} / \mathrm{mL}\end{array}$ & $\begin{array}{r}4 \times 10^{3}-4 \times \\
10^{8} \mathrm{CFU} / \mathrm{mL}\end{array}$ & [79] \\
\hline Amperometric & Genosensor & Cd NPs & CV-EIS-DPV & $1.97 \times 10^{-14} \mathrm{M}$ & $\begin{array}{c}1.94 \times 10^{-13} \\
\text { and } 2.01 \times \\
10^{-14} \mathrm{M}\end{array}$ & [80] \\
\hline Amperometric & $\begin{array}{l}\text { Screen printed } \\
\text { interdigitated } \\
\text { electrode }\end{array}$ & $\begin{array}{l}\text { core-shell magnetic } \\
\text { beads and Au NPs }\end{array}$ & $\mathrm{CV}$ & $52 \mathrm{CFU} / \mathrm{mL}$ & $\begin{array}{l}10^{2}-10^{6} \\
\text { CFU/mL }\end{array}$ & [81] \\
\hline Amperometric & DNA based sensor & $\begin{array}{l}\text { 3-aminipropyl } \\
\text { triethoxysilane } \\
\text { (APTES) }\end{array}$ & $\mathrm{CA}$ & $0.8 \mathrm{fM}$ & $1 \mathrm{fM}-10 \mu \mathrm{M}$ & [82] \\
\hline Amperometric & Immunosensor & MNPs and Au NPs & DPV & $10 \mathrm{CFU} / \mathrm{mL}$ & $\begin{array}{l}10^{1}-10^{6} \\
\mathrm{CFU} / \mathrm{mL}\end{array}$ & [83] \\
\hline Amperometric & Genosensor & $\begin{array}{c}\text { Carboxylated } \\
\text { graphene nanoflakes } \\
(\mathrm{Cx}-\mathrm{Gnfs})\end{array}$ & CV-EIS-CA & $10^{-17} \mathrm{M}$ & $\begin{array}{c}10^{-6}-10^{-17} \\
\mathrm{M}\end{array}$ & [84] \\
\hline Amperometric & Genosensor & $\begin{array}{l}\text { Reduced graphene } \\
\text { oxide (rGO) }\end{array}$ & CV-EIS-CA & $10^{-15} \mathrm{M}$ & $\begin{array}{c}10^{-6}-10^{-17} \\
\mathrm{M}\end{array}$ & [84] \\
\hline Amperometric & Aptasensor & Au NPs & $\mathrm{CV}$ & $10 \mathrm{CFU} / \mathrm{mL}$ & $\begin{array}{c}10-10^{9} \\
\mathrm{CFU} / \mathrm{mL}\end{array}$ & [85] \\
\hline Potentiometric & $\begin{array}{l}\mathrm{pH} \text { sensitive } \\
\text { nanofibre }\end{array}$ & $\begin{array}{c}\text { poly(vinyl } \\
\text { alcohol)/poly(acrylic } \\
\text { acid) (PVA/PAA) } \\
\text { hydrogel NFs }\end{array}$ & - & $10^{2} \mathrm{CFU} / \mathrm{mL}$ & $\begin{array}{l}10^{2}-10^{6} \\
\text { CFU/mL }\end{array}$ & [86] \\
\hline
\end{tabular}

Abbreviations: CV: Cyclic voltammetry, SWV: Square wave voltammetry, DPV: Differential pulse voltammetry, EIS: Electrochemical impedance spectroscopy, IS: Impedance spectroscopy, CA: Chronoamperometry, LSV: Linear sweep voltammetry. 


\subsection{Voltammetric-Based Biosensors}

Voltammetric measurement is based on the principle of measuring the flowing current produced through the working electrode dipped in a solution containing an electroactive species. The easy recognition of the target via its voltammetric peak potential qualifies voltammetry as a strong electrochemical technique in biosensing [44,87]. Cyclic voltammetry (CV), square wave voltammetry (SWV), and differential pulse voltammetry (DPV) are the frequently applied techniques in voltammetric biosensors. In the past few years, numerous approaches using aptamers, enzymes, and nanomaterials have been successfully incorporated into voltammetric biosensors for the detection of E. coli O 157:H7. Zhong and coworkers proposed a new electrochemical biosensor for the detection of E. coli O157:H7 (Figure 1). As signal-amplifying tags for the determination, cadmium sulfide quantum dots (CdS QDs) and encapsulated zeolite imidazolate framework-8 (ZIF-8) particles were used. In the presence of CdS QDs, the growth of ZIF-8, CdS@ZIF-8 muticore-shell particles on the sample was achieved. In order to introduce amino groups on the surface, CdS@ZIF-8 particles were coated via polyethyleneimine, followed by an anti-E. coli O157:H7 antibody modification on the surface for the selective detection of E. coli O157:H7. CdS@ZIF-8 particles, as signal tags, were used for preparing a sandwich-based sensor. By $\mathrm{HCl}$ leaching, $\mathrm{Cd}$ (II) ions were released from CdS@ZIF-8, leading to E. coli O157:H7 detection by differential pulse voltammetry. The linear range of 10 to $10^{8}$ colony forming units (CFU)/mL and $3 \mathrm{CFU} / \mathrm{mL}$ was achieved by the fabricated immunosensor which also showed good sensitivity and selectivity of E. coli O157:H7 in milk samples. The proposed biosensor can be expanded to be used for detection of other pathogenic bacteria [59]. Very recently, Yan li and coworkers [60] used multiple amplification strategies via 3D DNA walker, rolling circle amplification (RCA), and hybridization chain reaction (HCR) to develop a sensitive and selective electrochemical biosensor for the accurate determination of E. coli O157:H7 (Figure 2). The target sequence of the E. coli O157:H7 was extracted, transformed, and amplified. After that, in order to generate an enhanced electrochemical signal, a large sequence of double-stranded DNA as a result of HCR progress, immobilized electrochemical indicators. Based on the proposed strategy the detection limit was 7 CFU/mL for E. coli O157:H7 with a linear range of 10 to $10 \times 10^{4} \mathrm{CFU} / \mathrm{mL}$. The proposed multiple amplification strategy-based biosensor can be readily used for determination of different microorganisms, allowing a novel approach for early diagnosis of malignancies and monitoring the therapy responses [60]. The advantage of the voltammetric technique is that it provides highly sensitive measurements and the possibility of simultaneous detection of multiple analytes. This technique can provide low LODs of 2 CFU/mL using an electrochemical aptasensor detection strategy based on amino-functionalized metal-organic frameworks. Despite the low LOD achievements in some of the studies, testing the fabricated biosensors in real and complex samples remains to be done. Moreover, the detection time in most of the conducted studies was long, which needs to be improved. Research towards the simultaneous detection of E. coli O157:H7 in complex and real samples is also a major requirement. 


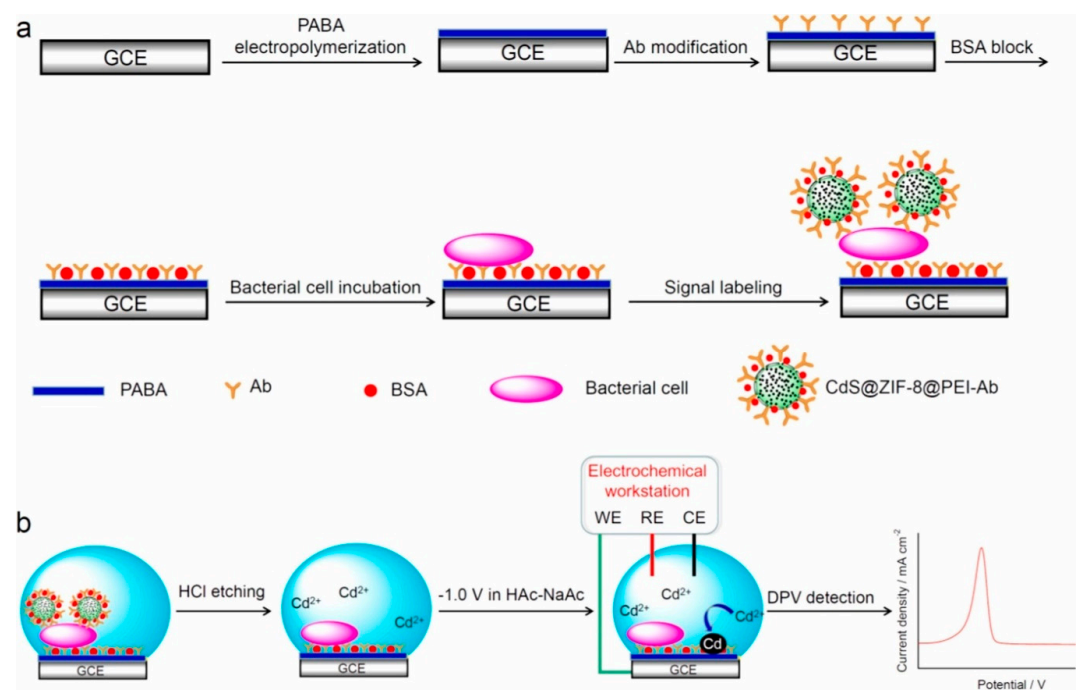

Figure 1. (a) Schematic diagram of the fabricated steps of the electrochemical biosensor for E. coli O157:H7 using CdS@ZIF-8 as signal tags, (b) Illustration of the detection steps by DPV. (GCE, glassy carbon electrode; PABA, Poly( $p$-aminobenzoic acid); Ab, antibody; BSA, bovine serum albumin; Cds, cadmium sulfide quantum dots; ZIF-8, zeolitic imidazolate framework-8; PEI, polyethyleneimine; WE, working electrode; RE, reference electrode; CE, counter electrode; HCL, hydrochloric acid; DPV, differential pulse voltammetry) [59].

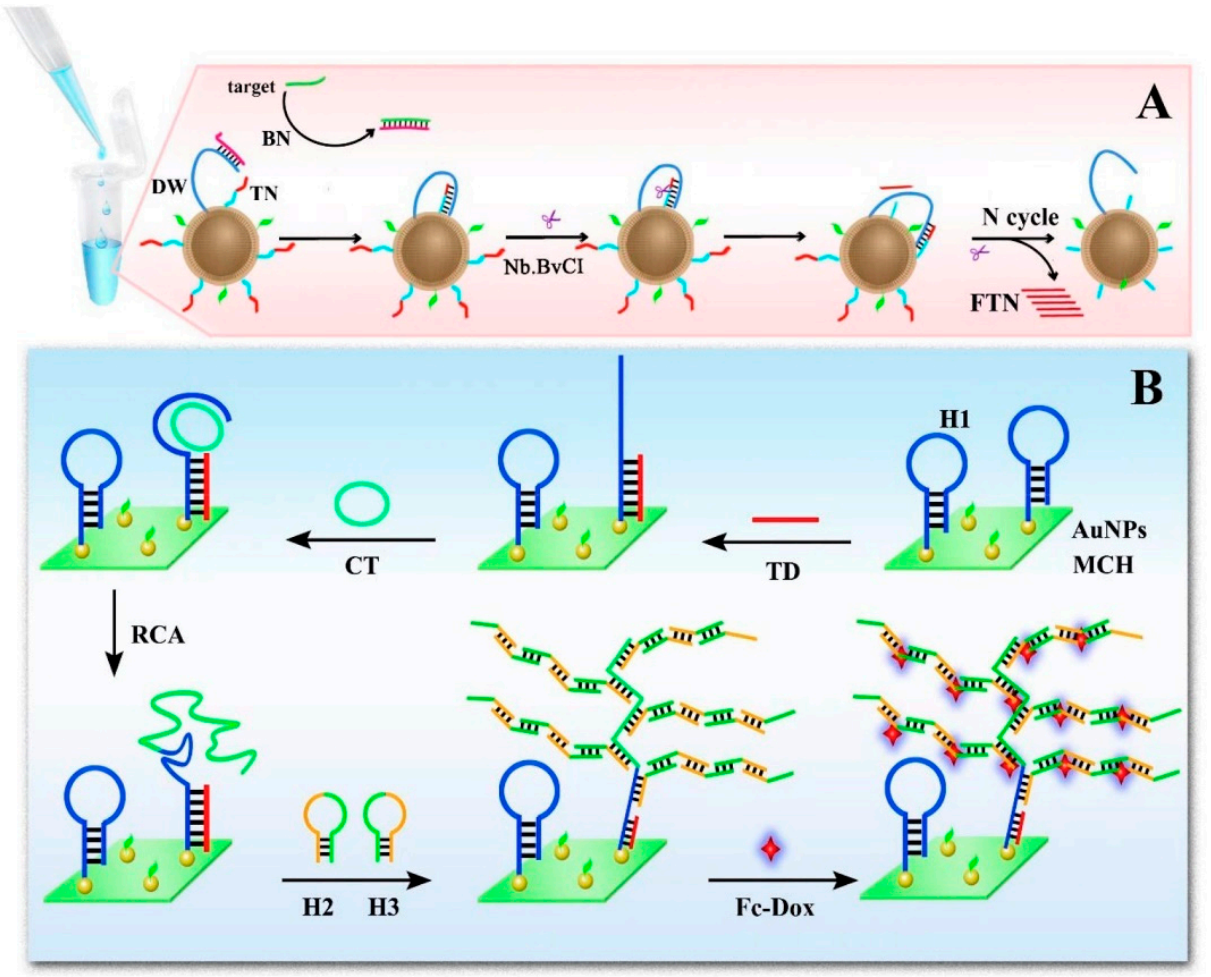

Figure 2. Schematic illustration of the electrochemical biosensor for E. coli O157:H7 detection. (A) Schematic illustration of the 3D DNA walker-based amplification reaction triggered by the target gene for transfer oligonucleotide fragment production; (B) Illustration of amplification reactions based on HCR and RCA on the surface of electrode to produce long double stranded DNA sequences for greater immobilization of electrochemical indicators associated with the target gene's concentration. (Au NPs, gold nanoparticles; BN, blocking DNA; CT, circular template; DW, DNA walker; FTN, fragment of TN; H1, hairpin DNA1; H2, hairpin DNA2; H3, hairpin DNA3; HCR, hybridization chain reaction; $\mathrm{MCH}$, 6-mercapto ethanol; RCA, rolling circle amplification; TN, transfer oligonucleotide) [60]. 


\subsection{Impedimetric Based Biosensors}

Impedimetric biosensors are one of the earliest approaches developed for rapid pathogen detection [88]. The main difference between this technique and other electrochemical techniques is conductivity detection [38]. Impedimetric biosensors work by analyzing the electron transfer at the electrode surface or measuring the solution/medium conductivity, which can be read as an impedance response [38]. The most frequently used technique for impedimetric biosensors is electrochemical impedance spectroscopy (EIS). This technique scans the detection volume and uses an electrical frequency sweep in the range of $10 \mathrm{KHz}$ to $10 \mathrm{MHz}[35,38]$. Electrochemical impedance spectroscopy (EIS) is an easily operated, simple, straightforward, and sensitive technique which has attracted substantial interest for E. coli O157:H7 determination. Barreiros de Santos and colleagues developed an indium tin oxide (ITO)-based impedimetric biosensor by using a robust, simple, and direct approach for the detection of E. coli O157:H7 (Figure 3). Immobilization of anti-E. coli antibodies onto ITO electrodes was done, and epoxy silane on the surface of ITO was attached covalently, as shown by atomic force microscopy and cyclic voltammetry. By using optical waveguide light mode spectroscopy (OWLS), antibody immobilization on the epoxy silane layer was quantified and a mass variation of $12 \mathrm{ng} \mathrm{cm}^{-2}$ $\left(0.08 \mathrm{pmol} \mathrm{cm}{ }^{-2}\right)$ was achieved. The selectivity of the antibodies and functionalization procedure's efficiency were confirmed by achieving a ratio of 1:500 Salmonella typhimurium/E. coli O157:H7. The proposed ITO-based immunosensor was evaluated by electrochemical impedance spectroscopy. A very low limit of detection of $1 \mathrm{CFU} \mathrm{mL}^{-1}$ with a large linear working range of $10-10^{6} \mathrm{CFU} \mathrm{mL}^{-1} \mathrm{was}^{-}$ achieved by using electrochemical impedance spectroscopy. The $20 \%$ detection of nonspecific bacteria, made up of E. coli K12 and S. typhimurium, showed the specificity of the impedimetric immunosensor, meaning that ITO is highly selective and sensitive [62]. Lan Yao and coworkers developed a microfluidic impedance biosensor for sensitive, rapid, and continuous E. coli O157:H7 detection by applying immune magnetic nanoparticles. For biological signal amplification, urease was used. In order to make the immune magnetic nanoparticles (MNPs), streptavidin-modified MNPs conjugated with biotinylated polyclonal antibodies were used. To make the MNP-bacteria complexes, the target is separated by the MNPs. Afterwards, to form the MNP-bacteria-gold nanoparticles (GNP)-urease complex, the gold nanoparticles modified with the urease and aptamers with the MNP-bacteria were conjugated. Then, hydrolysis of urea into ammonium carbonate led to impedance decrease. A low detection limit of $12 \mathrm{CFU} / \mathrm{mL}$ was obtained by online impedance measurement [64]. Recently, Martina Cimafonte and coworkers developed an electrochemical impedance immunosensor based on a screen-printed gold electrode by immobilizing anti-E. coli antibodies onto the gold surface covalently by the photochemical immobilization strategy for fast E. coli determination in water (Figure 4). In this study, in order to develop an "on-off" electrochemical impedimetric immunosensor, photochemical immobilization technique (PIT) was used for the first time in the functionalization of commercial gold electrodes using $\mathrm{Fe}(\mathrm{CN})_{6}{ }^{3-} / \mathrm{Fe}(\mathrm{CN})_{6}{ }^{4-}$ as a redox probe. E. coli in drinking water was selectively and sensitively detected with a limit of detection of $3 \times 10 \mathrm{CFU} / \mathrm{mL}$. The proposed biosensor needed no preconcentration or pre-enrichment steps for the detection process [73]. The ability to perform label-free detection is the most important advantage of impedimetric electrochemical biosensors; however, in some of the conducted studies, labels have been used for signal amplification. As shown in Table 2, by using an impedimetric sensing strategy, label-free direct detection of E. coli O157:H7 with a LOD of 1 CFU/mL was achieved. However, substantial time was required for the patterning of anti-E. coli O157 antibodies. Moreover, a low limit of quantification and testing of the fabricated biosensors in real and complex samples in most of the studies have not been achieved. 
(A)

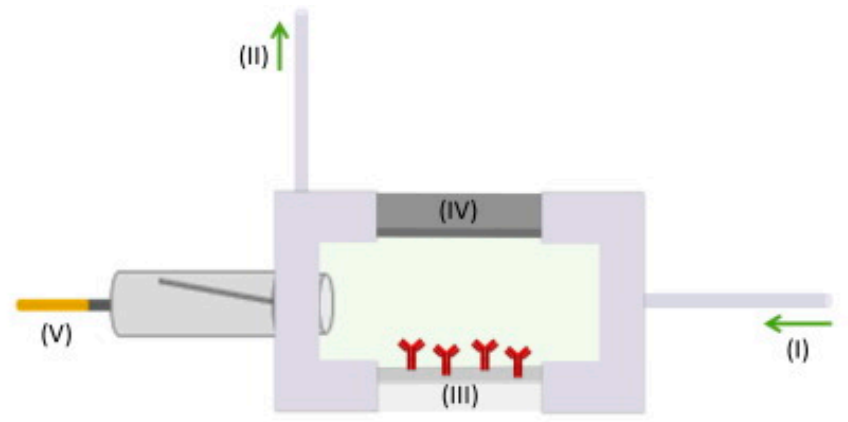

\section{Legend:}

(I) Inlet

(II) Outlet

(III) Working electrode (ITO)

(IV) Counter electrode

(V) Reference electrode

(B)

ITO

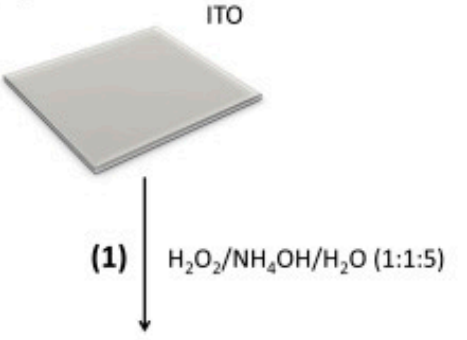

(2)

3-Glycidoxypropyldimethoxymethylsilane
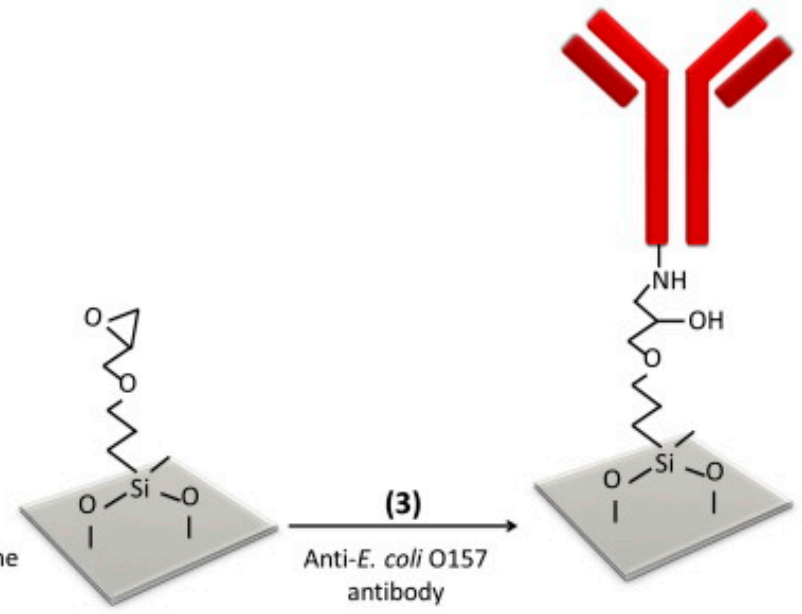

Figure 3. Schematic illustration of electrochemical cell (A) fabrication of immunosensor (B): hydroxylation (1), silanization (2), and antibody binding (3) [62].
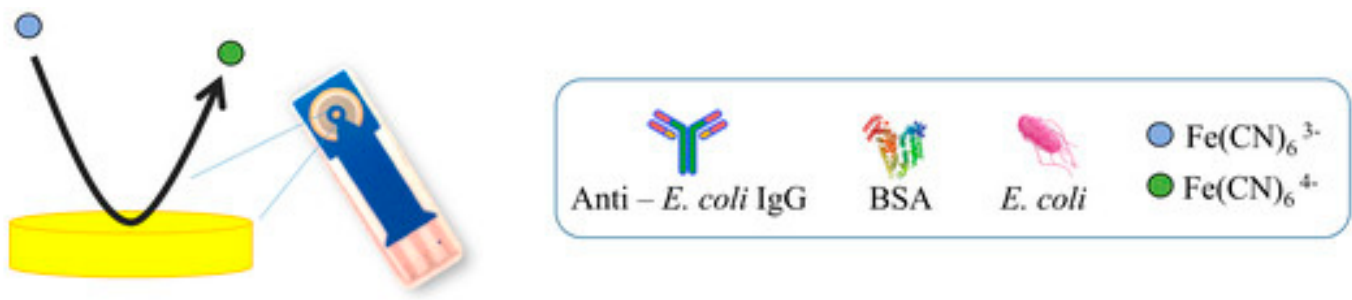

(I) $\mid$ Y
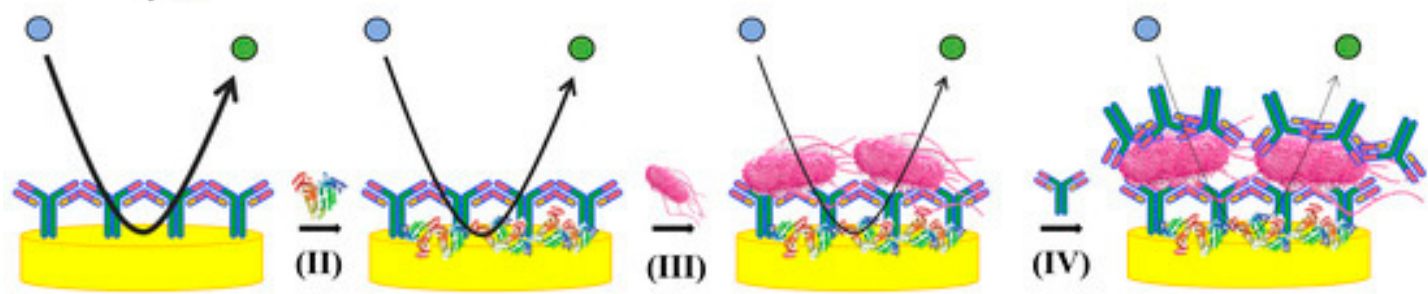

Figure 4. Schematic illustration of the stepwise functionalization and detection of the proposed immunosensor. The black line shows the redox reaction intensity, which is inhibited as the surface covering grows. Its thickness reduction is related to decrease of the "effective" area available for the electrolyte current, which is measured through an increase of the charge transfer resistance. (I: functionalization of the surface with antibodies, II: blocking the free remaining spaces on the gold electrode by BSA, III: reaction of immobilized antibodies and the E. coli cells, IV: conveying a fresh anti-E. coli Abs solution to the circuit) [73]. 


\subsection{Amperometric-Based Biosensors}

As a class of electrochemical biosensors, amperometric biosensors transduce the biological recognition reactions caused by electroactive agents at the electrode surface into a current signal to determine the target molecule within a sample matrix. They can be integrated with nucleic acids, enzymes, and antibody recognition elements, and are applicable for environmental monitoring [38,44]. Differential pulse voltammetry, cyclic voltammetry, and square wave voltammetry are different amperometric methods which are applied in biosensors. The false current reading because of the electroactive interference present in the sample matrix is the limitation of this technique, and can be solved by various methods such as changing the analyte, diluting the sample, etc. [38,44]. Ahmet Guner and coworkers developed a highly sensitive sandwich assay electrochemical immunosensor based on a Py, Pyrrole/gold nanoparticles/multiwalled carbon nanotube/chitosan (PPy/AuNP/MWCNT/Chi) hybrid nanobiocomposite-modified pencil graphite electrode (PGE) for E. coli O157:H7 detection (Figure 5). The hybrid bionanocomposite platform was modified with anti-E. coli O157:H7 monoclonal antibodies and the product was characterized by using cyclic voltammetry. A detection limit of $30 \mathrm{CFU} / \mathrm{mL}$ in PBS buffer with a linear range of $3 \times 10$ to $3 \times 10^{7} \mathrm{CFU} / \mathrm{mL}$ was achieved. For application in food quality and safety control, the produced sensor showed high stability and reproducibility [77]. In'another study, Lingxian Ye et al. proposed a sensitive point-of-care testing (POCT) with Au-Pt bimetallic nanoparticle ( $\mathrm{Au} @ \mathrm{Pt}$ )-functionalized silica nanoparticles ( $\mathrm{SiO}_{2} \mathrm{NPs}$ ) and $\mathrm{Fe}_{3} \mathrm{O}_{4}$ magnetic nanoparticles $\left(\mathrm{Fe}_{3} \mathrm{O}_{4} \mathrm{NPs}\right.$ ) for E. coli O157:H7 determination (Figure 6). As a negatively charged polyelectrolyte, poly-(4-styrenesulfonic acid-co-maleic acid) (PSSMA) coated on the amino group modified the $\mathrm{SiO}_{2}$ NPs surface, conferring electrostatic force. The PSSMA applied to connect the negatively charged $\mathrm{Au} @ \mathrm{Pt} \mathrm{NPs}$ to the $\mathrm{SiO}_{2} \mathrm{NPs}$ led to the formation of $\mathrm{Au} @ \mathrm{Pt} / \mathrm{SiO}_{2} \mathrm{NPs}$. As signal labels, antibody- and invertase-conjugated $\mathrm{Au} @ \mathrm{Pt} / \mathrm{SiO}_{2} \mathrm{NPs}$ were used. In order to enrich and capture the target in a positive sample, monoclonal antibody-functionalized magnetic nanoparticles $\left(\mathrm{Ab}-\mathrm{Fe}_{3} \mathrm{O}_{4} @ \mathrm{SiO}_{2} \mathrm{NPs}\right)$ were used. For the quantitative readout by the PGM, the invertase in the proposed sandwich assay catalyzed the hydrolysis of sucrose to generate a large amount of glucose. A low detection limit of $1.83 \times 10^{2} \mathrm{CFU} / \mathrm{mL}$ was achieved [76]. Electrochemical biosensors based on amperometry have the advantages of high sensitivity, rapid, low cost, and robustness with the possibility of portability. Focusing of these aspects, more studies need to be performed in order to provide a portable sensitive biosensor for the detection of E. coli O157. Multiplexing detection and assessing the reproducibility are other parameters which should be focused on while conducting future studies based on amperometry. As the limit of quantification is rarely calculated in the reviewed studies, it also should be included to enable comparison between the reported studies.

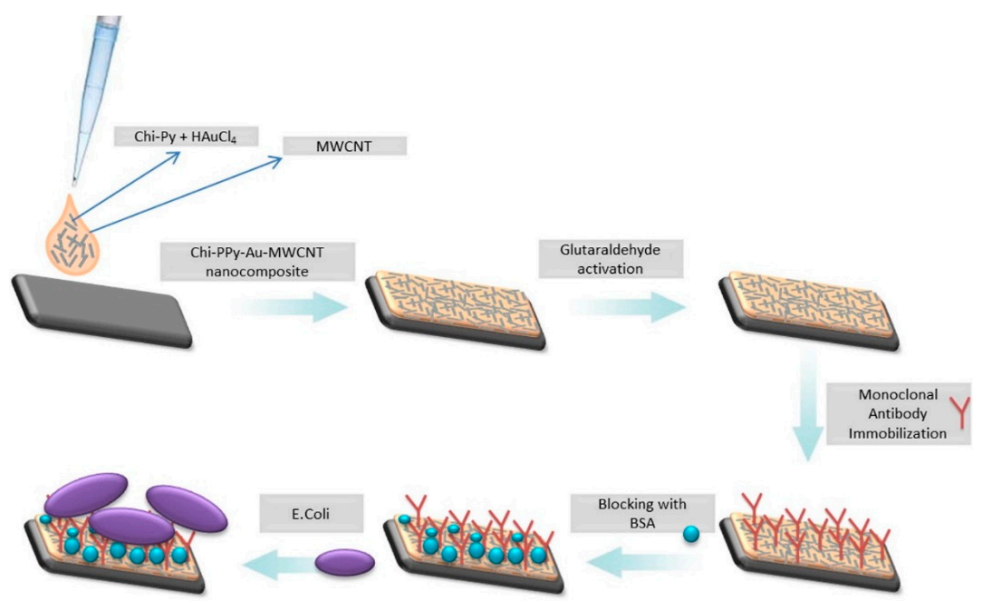

Figure 5. Schematic illustration of the experimental setup of the immunosensor [77]. 
(A)

(B)
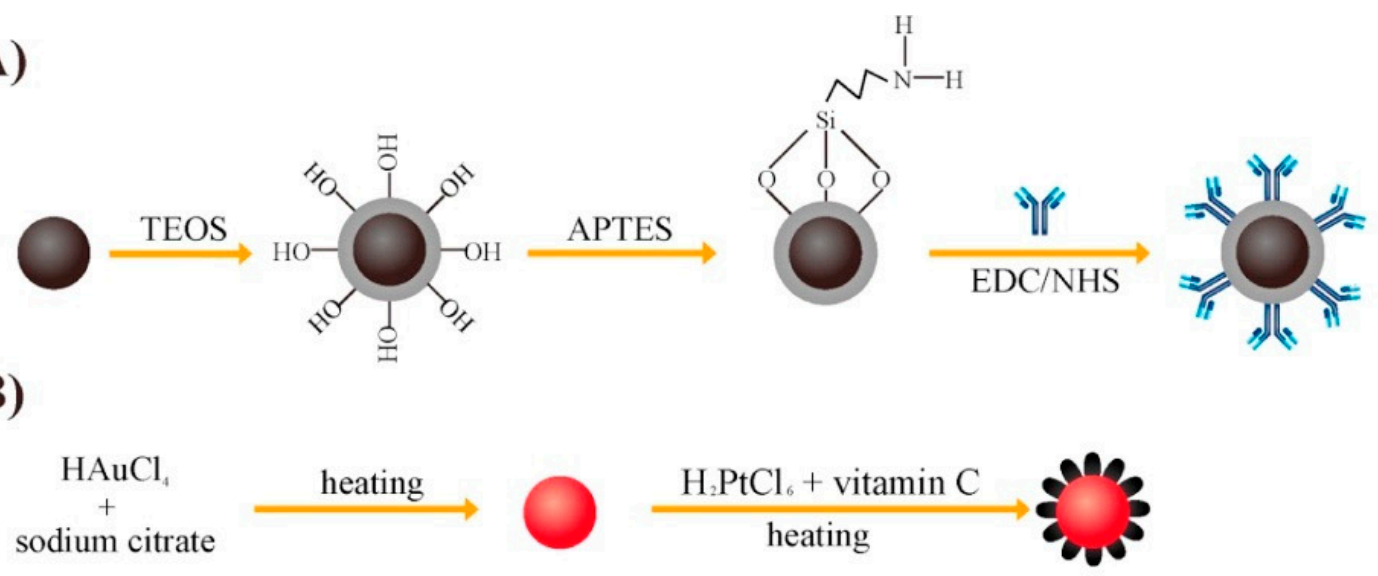

(C)

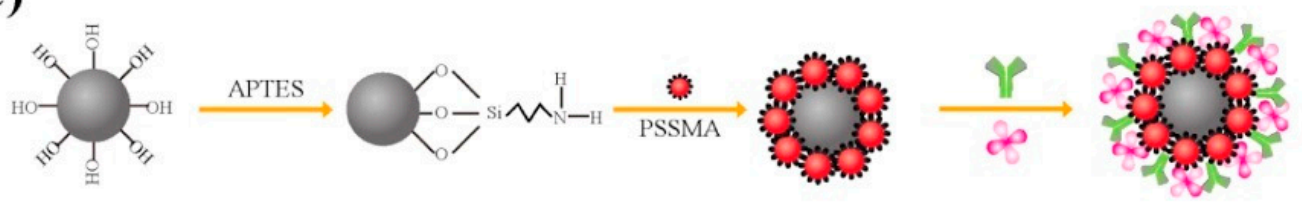

(D)
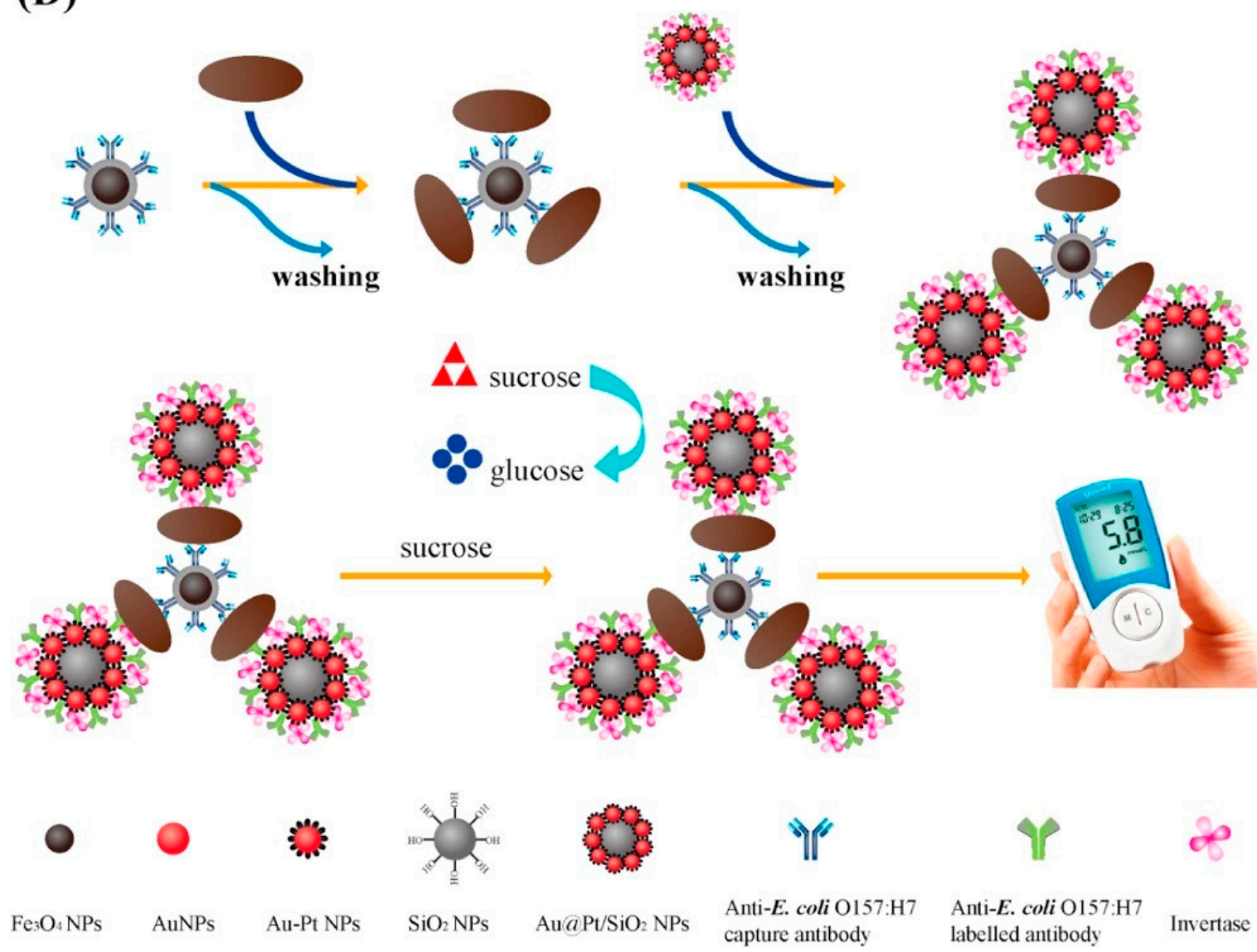

Figure 6. A schematic diagram of the preparation process of $\mathrm{Ab}-\mathrm{Fe}_{3} \mathrm{O}_{4} @ \mathrm{SiO}_{2} \mathrm{NPs}(\mathrm{A}), \mathrm{Au} @ \mathrm{Pt} \mathrm{NPs}$ (B), $\mathrm{Ab} /$ invertase- $\mathrm{Au} @ \mathrm{Pt} / \mathrm{SiO}_{2} \mathrm{NPs}(\mathrm{C})$; Experimental process of E. coli O157:H7 detection employing

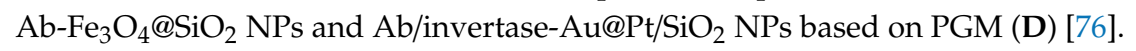




\subsection{Potentiometric-Based Portable Baiosensors}

Recently, efforts have been focused on the design of portable sensors for low-cost, on-site, and fast E. coli O157:H7 detection due to the zero-tolerance policy concerning its presence in food. The portability of electrochemical biosensors is of critical importance to realize in-field determination of foodborne and waterborne microorganisms [35]. Few electrochemical lab-on-a-chip and portable biosensors have been made for E. coli determination. Potentiometric biosensors, as low-cost, small, and highly sensitive and selective sensors, apply an ion-selective electrode and ion-sensitive field effect transistor to acquire analytical data [38]. Recently, Parmiss Mojir Shaibani and coworkers (Figure 7) reported a paper for the detection of $E$. coli in orange juice using a portable nanofiber-light addressable potentiometric sensor (NF-LAPS). As the sensitive layer, electrospun pH-sensitive poly (vinyl alcohol)/poly(acrylic acid) (PVA/PAA) hydrogel NFs was chosen. A limit of detection of $100 \mathrm{CFU} / \mathrm{mL}$ was obtained selectively in less than one hour by using NF-LAPS [86].

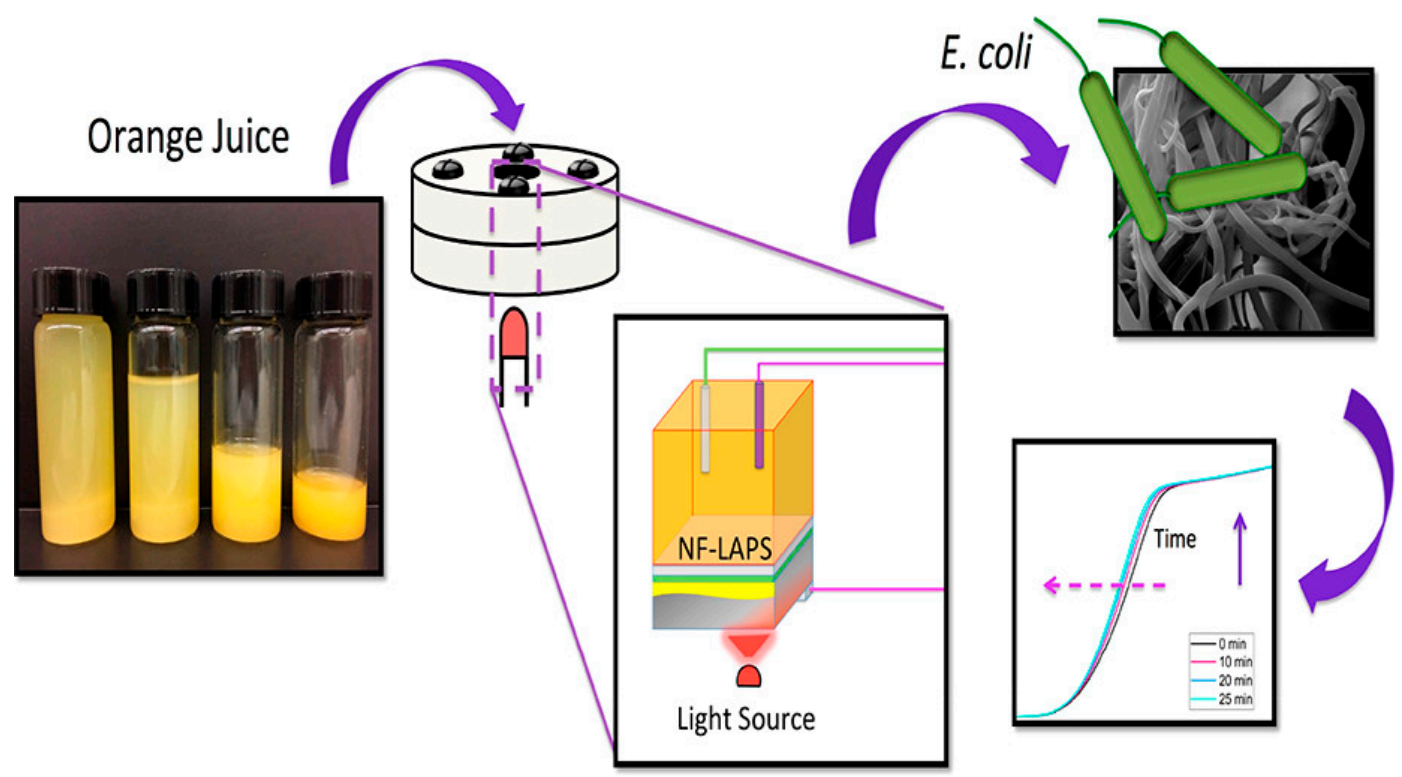

Figure 7. Schematic illustration of the nanofiber-light addressable potentiometric sensor (NF-LAPS) sensor comprising a three-electrode system [86].

\subsection{Nanoimpact Method}

During the last decade, a powerful new electrochemical technique named the "nanoimpact method" has been developed for single bacterial cell characterization and detection. The method is based on the Faradaic charge transfer following particle collision. Diffusional Brownian motion causes particle movement, and due to the interaction of suspended particles with the electrode, under an oxidizing potential, a short current burst results from the interaction between the particles and the electrode [89]. The detection of the nanoimpact is performed using the change in diffusion current. Lee et al. [90] has reported a fast electrochemical label-free approach through current blockages caused by collision events for $E$. coli single cell detection on an ultramicroelectrode. The ferrocyanide-ferricyanide redox couple was used in this study. This methodology has the capability to be used to study other pathogenic bacteria and different target molecules [90]. The problem with the surface blockage detection strategy is the lack of selectivity between various bacterial species and dead and alive cells. In another study, Couto and coworkers [91] applied a carbon microelectrode for fast redox mediated detection of E. coli using impact electrochemistry. N,N, $\mathrm{N}^{\prime}, \mathrm{N}^{\prime}$-tetramethyl-1,4-phenylenediamine (TMPD) was used as a redox mediator to interact with cytochrome c oxidases of bacteria and obtain an electrochemical current, or "on" signals. The advantage of this system is the minimization of false-positive signals. 
The integration of the reported study with microfluidic devices may lead to the low concentration detection of bacteria [91].

\section{Conclusions and Future Perspectives}

Bacterial detection is very important in water monitoring, environmental assessment, and the food industry. E. coli O157:H7 has caused several outbreaks worldwide since its first recognition. Thus, the detection of E. coli O157:H7 is one of the major challenges to prevent severe outbreaks. Although currently available methods are highly sensitive, they require a long time to perform and are labor-intensive; therefore, there is a demand for a rapid, simple, sensitive, and low-cost alternative. Among the different types of transducers, electrochemical biosensors, owing to their fast response, selectivity, low cost, sensitivity, possibility of miniaturization, and capability of being integrated into one device, are extensively studied and well developed for the detection of Escherichia coli O157:H7. In this review, the recent developments of label and label-free electrochemical biosensors for the detection of Escherichia coli O157:H7 have been summarized. Although label-free methodologies have the advantages of direct and simple detection with a relatively low detection time and possibility of integration into one test chip, the lack of additional signal amplification and the incubation of the target bacteria with the electrodes are the main disadvantages. To overcome the interference of nontarget molecules in label-free biosensors, appropriate selection of more specific bioreceptors, such as aptamers, etc., is necessary. As illustrated in Table 2, most of the recent chemical recognition approaches involve affinity sensing strategies using aptamers and antibodies as bioreceptors. Aptamers with similar affinity and specificity are chemically stable, small, and they have a simple development process, high target potential, and less production time and cost compared to antibodies. Despite some advantages that aptamers over antibodies, some of the recent studies overviewed in this manuscript are immunosensors based on immobilized antibodies using different kinds of linkages, such as gold nanoparticles. This may be because antibodies are an established technology in all labs, whereas aptamer commercialization has not occurred as quickly as expected. However, the appropriate orientation of antibodies is the most important factor for the improvement of the performance of antibody-based immunosensors in terms of specificity and sensitivity, and the appropriate selection of nanomaterials could overcome this problem. Nanotechnology is an emerging field in science and different nanomaterials, especially gold nanoparticles, have been integrated in the development of electrochemical biosensors for E. coli O157:H7 detection. Nanomaterials are highly important for the immobilization of bioaffinity agents for label-free strategies, and further research should be conducted on the improvement of novel nano-scale materials for effective electron transduction. Current progress in nanotechnology is growing; further studies regarding nanomaterial stability and toxicity in aqueous environments and further progress of smart nanomaterials with useful functions with low cost are expected to solve the improve the sensitivity of electrochemical biosensors towards E. coli O157:H7 detection. Because of the relatively large size of whole bacteria compared to typical biological targets and the existence of different epitopes on the surface of bacteria that can lead to nonspecificity of the approach, a product for real sample applications and the commercial market is yet to be successfully developed. Although impact electrochemistry, as a promising and sensitive technique, has gained attention for E. coli bacteria sensing at the single cell scale, selectivity is the main challenge of this technique. Digital microfluidics, as portable and stable platforms with the power of automation, have the capability to overcome the limitations of current analytical methods in real-time applications, but remain challenging. Overall, sensitivity, specificity, stability, detection time, sample processing, size, ability to perform in different conditions, and no special training requirement are the key features of a biosensor. In addressing all these issues, electrochemical biosensors have a long way to go, but collaboration between academia and industry can pave the way for developing a desirable, portable product. 
Funding: This research was funded by the European Union's Horizon 2020 research and innovation program under the Marie Skłodowska-Curie grant agreement No: H2020-MSCA-ITN-2018-813680.

Acknowledgments: Authors gratefully acknowledge the financial support and funding from the European Union's Horizon 2020 research and innovation program under the Marie Skłodowska-Curie grant agreement No: H2020-MSCA-ITN-2018-813680.

Conflicts of Interest: The authors declare no conflict of interest.

\section{References}

1. Tarditto, L.V.; Arévalo, F.J.; Zon, M.A.; Ovando, H.G.; Vettorazzi, N.R.; Fernández, H. Electrochemical sensor for the determination of enterotoxigenic Escherichia coli in swine feces using glassy carbon electrodes modified with multi-walled carbon nanotubes. Microchem. J. 2016, 127, 220-225. [CrossRef]

2. Banerjee, T.; Sulthana, S.; Shelby, T.; Heckert, B.; Jewell, J.; Woody, K.; Karimnia, V.; McAfee, J.; Santra, S. Multiparametric magneto-fluorescent nanosensors for the ultrasensitive detection of Escherichia coli O157: H7. ACS Infect. Dis. 2016, 2, 667-673. [CrossRef] [PubMed]

3. Kim, S.U.; Jo, E.-J.; Mun, H.; Noh, Y.; Kim, M.-G. Ultrasensitive detection of Escherichia coli O157: H7 by immunomagnetic separation and selective filtration with nitroblue tetrazolium/5-bromo-4-chloro-3-indolyl phosphate signal amplification. J. Agric. Food Chem. 2018, 66, 4941-4947. [CrossRef] [PubMed]

4. Li, T.; Zhu, F.; Guo, W.; Gu, H.; Zhao, J.; Yan, M.; Liu, S. Selective capture and rapid identification of E. coli O157: H7 by carbon nanotube multilayer biosensors and microfluidic chip-based LAMP. RSC Adv. 2017, 7, 30446-30452. [CrossRef]

5. Chen, R.; Huang, X.; Li, J.; Shan, S.; Lai, W.; Xiong, Y. A novel fluorescence immunoassay for the sensitive detection of Escherichia coli O157: H7 in milk based on catalase-mediated fluorescence quenching of CdTe quantum dots. Anal. Chim. Acta 2016, 947, 50-57. [CrossRef] [PubMed]

6. Liu, J.-T.; Settu, K.; Tsai, J.-Z.; Chen, C.-J. Impedance sensor for rapid enumeration of E. coli in milk samples. Electrochim. Acta 2015, 182, 89-95. [CrossRef]

7. Wu, W.; Zhao, S.; Mao, Y.; Fang, Z.; Lu, X.; Zeng, L. A sensitive lateral flow biosensor for Escherichia coli O157: H7 detection based on aptamer mediated strand displacement amplification. Anal. Chim. Acta 2015, 861, 62-68. [CrossRef]

8. Chen, M.; Yu, Z.; Liu, D.; Peng, T.; Liu, K.; Wang, S.; Xiong, Y.; Wei, H.; Xu, H.; Lai, W. Dual gold nanoparticle lateflow immunoassay for sensitive detection of Escherichia coli O157: H7. Anal. Chim. Acta 2015, 876, 71-76. [CrossRef]

9. Mortality and Burden of Disease from Water and Sanitation. Available online: https://www.who.int/gho/phe/ water_sanitation/burden_text/en/ (accessed on 1 April 2020).

10. World Health Organization. WHO's Work on Food Safety. Available online: https://www.who.int/healthtopics/food-safety/ (accessed on 15 May 2020).

11. Ngamsom, B.; Truyts, A.; Fourie, L.; Kumar, S.; Tarn, M.D.; Iles, A.; Moodley, K.; Land, K.J.; Pamme, N. A microfluidic device for rapid screening of E. coli O157: H7 based on IFAST and ATP bioluminescence assay for water analysis. Chem. Eur. J. 2017, 23, 12754-12757. [CrossRef]

12. Clements, A.; Young, J.C.; Constantinou, N.; Frankel, G. Infection strategies of enteric pathogenic Escherichia coli. Gut Microbes 2012, 3, 71-87. [CrossRef]

13. Croxen, M.A.; Law, R.J.; Scholz, R.; Keeney, K.M.; Wlodarska, M.; Finlay, B.B. Recent advances in understanding enteric pathogenic Escherichia coli. Clin. Microbiol. Rev. 2013, 26, 822-880. [CrossRef]

14. Huang, S.-W.; Hsu, B.-M.; Su, Y.-J.; Ji, D.-D.; Lin, W.-C.; Chen, J.-L.; Shih, F.-C.; Kao, P.-M.; Chiu, Y.-C. Occurrence of diarrheagenic Escherichia coli genes in raw water of water treatment plants. Environ. Sci. Pollut. Res. 2012, 19, 2776-2783. [CrossRef]

15. Kaper, J.B.; Nataro, J.P.; Mobley, H.L. Pathogenic escherichia coli. Nat. Rev. Microbiol. 2004, 2, $123-140$. [CrossRef] [PubMed]

16. Balakrishnan, B.; Barizuddin, S.; Wuliji, T.; El-Dweik, M. A rapid and highly specific immunofluorescence method to detect Escherichia coli O157: H7 in infected meat samples. Int. J. Food Microbiol. 2016, 231, 54-62. [CrossRef] [PubMed] 
17. Cui, X.; Huang, Y.; Wang, J.; Zhang, L.; Rong, Y.; Lai, W.; Chen, T. A remarkable sensitivity enhancement in a gold nanoparticle-based lateral flow immunoassay for the detection of Escherichia coli O157: H7. RSC Adv. 2015, 5, 45092-45097. [CrossRef]

18. Padola, N.L.; Etcheverría, A.I. Shiga toxin-producing Escherichia coli in human, cattle, and foods. Strategies for detection and control. Front. Cell. Infect. Microbiol. 2014, 4, 89. [CrossRef]

19. Wendel, A.M.; Johnson, D.H.; Sharapov, U.; Grant, J.; Archer, J.R.; Monson, T.; Koschmann, C.; Davis, J.P. Multistate outbreak of Escherichia coli O157: H7 infection associated with consumption of packaged spinach, August-September 2006: The Wisconsin investigation. Clin. Infect. Dis. 2009, 48, 1079-1086. [CrossRef]

20. Ten, S.; Hashim, U.; Gopinath, S.; Liu, W.; Foo, K.; Sam, S.; Rahman, S.; Voon, C.; Nordin, A. Highly sensitive Escherichia coli shear horizontal surface acoustic wave biosensor with silicon dioxide nanostructures. Biosens. Bioelectron. 2017, 93, 146-154. [CrossRef]

21. Andrews, W.H.; Jacobson, A.; Hammack, T. Bacteriological Analytical Manual (BAM); AOAC International: Rockville, MD, USA, 2011.

22. Tadesse, D.A.; Zhao, S.; Tong, E.; Ayers, S.; Singh, A.; Bartholomew, M.J.; McDermott, P.F. Antimicrobial drug resistance in Escherichia coli from humans and food animals, United States, 1950-2002. Emerg. Infect. Dis. 2012, 18, 741. [CrossRef]

23. Schüller, S.; Phillips, A.D. Microaerobic conditions enhance type III secretion and adherence of enterohaemorrhagic Escherichia coli to polarized human intestinal epithelial cells. Environ. Microbiol. 2010, 12, 2426-2435. [CrossRef] [PubMed]

24. Zhu, H.; Sikora, U.; Ozcan, A. Quantum dot enabled detection of Escherichia coli using a cell-phone. Analyst 2012, 137, 2541-2544. [CrossRef] [PubMed]

25. Menne, J.; Nitschke, M.; Stingele, R.; Abu-Tair, M.; Beneke, J.; Bramstedt, J.; Bremer, J.P.; Brunkhorst, R.; Busch, V.; Dengler, R. Validation of treatment strategies for enterohaemorrhagic Escherichia coli O104: H4 induced haemolytic uraemic syndrome: Case-control study. BMJ 2012, 345, e4565. [CrossRef] [PubMed]

26. Wan, J.; Ai, J.; Zhang, Y.; Geng, X.; Gao, Q.; Cheng, Z. Signal-off impedimetric immunosensor for the detection of Escherichia coli O157: H7. Sci. Rep. 2016, 6, 19806. [CrossRef]

27. Song, C.; Li, J.; Liu, J.; Liu, Q. Simple sensitive rapid detection of Escherichia coli O157: H7 in food samples by label-free immunofluorescence strip sensor. Talanta 2016, 156, 42-47. [CrossRef] [PubMed]

28. Kim, J.; Kim, M.; Kim, S.; Ryu, S. Sensitive detection of viable Escherichia coli O157: H7 from foods using a luciferase-reporter phage phiV10lux. Int. J. Food Microbiol. 2017, 254, 11-17. [CrossRef] [PubMed]

29. Yang, H.; Zhou, H.; Hao, H.; Gong, Q.; Nie, K. Detection of Escherichia coli with a label-free impedimetric biosensor based on lectin functionalized mixed self-assembled monolayer. Sens. Actuators B Chem. 2016, 229, 297-304. [CrossRef]

30. Ravan, H.; Amandadi, M.; Sanadgol, N. A highly specific and sensitive loop-mediated isothermal amplification method for the detection of Escherichia coli O157: H7. Microb. Pathog. 2016, 91, 161-165. [CrossRef] [PubMed]

31. Sun, X.; Lei, C.; Guo, L.; Zhou, Y. Separable detecting of Escherichia coli O157H: H7 by a giant magneto-resistance-based bio-sensing system. Sens. Actuators B Chem. 2016, 234, 485-492. [CrossRef]

32. Gracias, K.S.; McKillip, J.L. A review of conventional detection and enumeration methods for pathogenic bacteria in food. Can. J. Microbiol. 2004, 50, 883-890. [CrossRef]

33. Jiang, Y.; Zou, S.; Cao, X. A simple dendrimer-aptamer based microfluidic platform for E. coli O157: H7 detection and signal intensification by rolling circle amplification. Sens. Actuators B Chem. 2017, 251, 976-984. [CrossRef]

34. Wang, H.; Zhao, Y.; Bie, S.; Suo, T.; Jia, G.; Liu, B.; Ye, R.; Li, Z. Development of an electrochemical biosensor for rapid and effective detection of pathogenic Escherichia coli in licorice extract. Appl. Sci. 2019, 9, 295. [CrossRef]

35. Xu, M.; Wang, R.; Li, Y. Electrochemical biosensors for rapid detection of Escherichia coli O157: H7. Talanta 2017, 162, 511-522. [CrossRef] [PubMed]

36. Law, J.W.-F.; Ab Mutalib, N.-S.; Chan, K.-G.; Lee, L.-H. Rapid methods for the detection of foodborne bacterial pathogens: Principles, applications, advantages and limitations. Front. Microbiol. 2015, 5, 770. [CrossRef]

37. Turner, A.P. Biosensors: Sense and sensibility. Chem. Soc. Rev. 2013, 42, 3184-3196. [CrossRef]

38. Perumal, V.; Hashim, U. Advances in biosensors: Principle, architecture and applications. J. Appl. Biomed. 2014, 12, 1-15. [CrossRef] 
39. da Silva, E.T.; Souto, D.E.; Barragan, J.T.; de F. Giarola, J.; de Moraes, A.C.; Kubota, L.T. Electrochemical biosensors in point-of-care devices: Recent advances and future trends. ChemElectroChem 2017, 4, 778-794. [CrossRef]

40. Srivastava, K.R.; Awasthi, S.; Mishra, P.K.; Srivastava, P.K. Biosensors/molecular tools for detection of waterborne pathogens. In Waterborne Pathogens; Elsevier: Amsterdam, The Netherlands, 2020; pp. 237-277.

41. Thévenot, D.R.; Toth, K.; Durst, R.A.; Wilson, G.S. Electrochemical biosensors: Recommended definitions and classification. Anal. Lett. 2001, 34, 635-659. [CrossRef]

42. Thevenot, D.R.; Toth, K.; Durst, R.A.; Wilson, G.S. Electrochemical biosensors: Recommended definitions and classification. Pure Appl. Chem. 1999, 71, 2333-2348. [CrossRef]

43. Wang, Y.; Xu, H.; Zhang, J.; Li, G. Electrochemical sensors for clinic analysis. Sensors 2008, 8, $2043-2081$. [CrossRef]

44. Hammond, J.L.; Formisano, N.; Estrela, P.; Carrara, S.; Tkac, J. Electrochemical biosensors and nanobiosensors. Essays Biochem. 2016, 60, 69-80. [PubMed]

45. Mehrotra, P. Biosensors and their applications-A review. J. Oral Biol. Craniofacial Res. 2016, 6, 153-159. [CrossRef]

46. Kavita, V. DNA biosensors-A review. J. Bioeng. Biomed. Sci. 2017, 7, 222.

47. Kumar, S.; Nehra, M.; Mehta, J.; Dilbaghi, N.; Marrazza, G.; Kaushik, A. Point-of-care strategies for detection of waterborne pathogens. Sensors 2019, 19, 4476. [CrossRef] [PubMed]

48. Mobed, A.; Baradaran, B.; de la Guardia, M.; Agazadeh, M.; Hasanzadeh, M.; Rezaee, M.A.; Mosafer, J.; Mokhtarzadeh, A.; Hamblin, M.R. Advances in detection of fastidious bacteria: From microscopic observation to molecular biosensors. TrAC Trends Anal. Chem. 2019, 113, 157-171. [CrossRef]

49. Cinti, S.; Volpe, G.; Piermarini, S.; Delibato, E.; Palleschi, G. Electrochemical biosensors for rapid detection of foodborne Salmonella: A critical overview. Sensors 2017, 17, 1910. [CrossRef]

50. Pandey, V.K.; Mishra, P.K. Nanoconjugates for detection of waterborne bacterial pathogens. In Waterborne Pathogens; Elsevier: Amsterdam, The Netherlands, 2020; pp. 363-384.

51. Wang, Y.; Fewins, P.A.; Alocilja, E.C. Electrochemical immunosensor using nanoparticle-based signal enhancement for Escherichia coli O157: H7 detection. IEEE Sens. J. 2015, 15, 4692-4699. [CrossRef]

52. Housaindokht, M.R.; Verdian, A.; Sheikhzadeh, E.; Pordeli, P.; Rouhbakhsh Zaeri, Z.; Janati Fard, F.; NOSRATI, M.; Mashreghi, M.; Haghparast, A.; Nakhaei Pour, A. A sensitive electrochemical aptasensor based on single wall carbon nanotube modified screen printed electrode for detection of Escherichia coli O157: H7. Adv. Mater. Lett. 2018, 9, 369-374. [CrossRef]

53. Guo, Y.; Wang, Y.; Liu, S.; Yu, J.; Wang, H.; Cui, M.; Huang, J. Electrochemical immunosensor assay (EIA) for sensitive detection of E. coli O157: H7 with signal amplification on a SG-PEDOT-AuNPs electrode interface. Analyst 2015, 140, 551-559. [CrossRef]

54. Tiwari, I.; Singh, M.; Pandey, C.M.; Sumana, G. Electrochemical detection of a pathogenic Escherichia coli specific DNA sequence based on a graphene oxide-chitosan composite decorated with nickel ferrite nanoparticles. RSC Adv. 2015, 5, 67115-67124. [CrossRef]

55. Nguyen, D.Q.; Ishiki, K.; Shiigi, H. Single cell immunodetection of Escherichia coli O157: H7 on an indium-tin-oxide electrode by using an electrochemical label with an organic-inorganic nanostructure. Microchim. Acta 2018, 185, 465. [CrossRef] [PubMed]

56. Shahrokhian, S.; Ranjbar, S. Aptamer immobilization on amino-functionalized metal-organic frameworks: An ultrasensitive platform for the electrochemical diagnostic of Escherichia coli O157: H7. Analyst 2018, 143, 3191-3201. [CrossRef] [PubMed]

57. Shoaie, N.; Forouzandeh, M.; Omidfar, K. Voltammetric determination of the Escherichia coli DNA using a screen-printed carbon electrode modified with polyaniline and gold nanoparticles. Microchim. Acta 2018, 185, 217. [CrossRef] [PubMed]

58. Ismail, N.A.B.; Ahmed, N.A.; Abd-Wahab, F.; Ramli, N.I.; Salim, W.W.A.W. Detection of Nonspecific Binding of E. coli O157: H7 on Reduced Graphene Oxide Screen-Printed Carbon Electrodes Using Electrochemical Methods. Preprints 2018, 2018100631. [CrossRef]

59. Zhong, M.; Yang, L.; Yang, H.; Cheng, C.; Deng, W.; Tan, Y.; Xie, Q.; Yao, S. An electrochemical immunobiosensor for ultrasensitive detection of Escherichia coli O157: H7 using CdS quantum dots-encapsulated metal-organic frameworks as signal-amplifying tags. Biosens. Bioelectron. 2019, 126, 493-500. [CrossRef] 
60. Li, Y.; Liu, H.; Huang, H.; Deng, J.; Fang, L.; Luo, J.; Zhang, S.; Huang, J.; Liang, W.; Zheng, J. A sensitive electrochemical strategy via multiple amplification reactions for the detection of E. coli O157: H7. Biosens. Bioelectron. 2020, 147, 111752. [CrossRef]

61. Xu, M.; Wang, R.; Li, Y. Rapid detection of Escherichia coli O157: H7 and Salmonella Typhimurium in foods using an electrochemical immunosensor based on screen-printed interdigitated microelectrode and immunomagnetic separation. Talanta 2016, 148, 200-208. [CrossRef]

62. Dos Santos, M.B.; Azevedo, S.; Agusil, J.; Prieto-Simón, B.; Sporer, C.; Torrents, E.; Juárez, A.; Teixeira, V.; Samitier, J. Label-free ITO-based immunosensor for the detection of very low concentrations of pathogenic bacteria. Bioelectrochemistry 2015, 101, 146-152. [CrossRef]

63. Pandey, C.M.; Tiwari, I.; Singh, V.N.; Sood, K.; Sumana, G.; Malhotra, B.D. Highly sensitive electrochemical immunosensor based on graphene-wrapped copper oxide-cysteine hierarchical structure for detection of pathogenic bacteria. Sens. Actuators B Chem. 2017, 238, 1060-1069. [CrossRef]

64. Yao, L.; Wang, L.; Huang, F.; Cai, G.; Xi, X.; Lin, J. A microfluidic impedance biosensor based on immunomagnetic separation and urease catalysis for continuous-flow detection of E. coli O157: H7. Sens. Actuators B Chem. 2018, 259, 1013-1021. [CrossRef]

65. Li, Z.; Fu, Y.; Fang, W.; Li, Y. Electrochemical impedance immunosensor based on self-assembled monolayers for rapid detection of Escherichia coli O157: H7 with signal amplification using lectin. Sensors 2015, 15, 19212-19224. [CrossRef] [PubMed]

66. Yang, Z.; Liu, Y.; Lei, C.; Sun, X.-c.; Zhou, Y. Ultrasensitive detection and quantification of E. coli O157: H7 using a giant magnetoimpedance sensor in an open-surface microfluidic cavity covered with an antibody-modified gold surface. Microchim. Acta 2016, 183, 1831-1837. [CrossRef]

67. Dastider, S.G.; Barizuddin, S.; Yuksek, N.; Dweik, M.; Almasri, M. Impedance Biosensor for Rapid Detection of Low Concentration of E. coli 0157: H7. In Proceedings of the IEEE 29th International Conference on Micro Electro Mechanical Systems (MEMS), Shanghai, China, 24-28 January 2016; pp. 302-306.

68. Abdullah, A.; Jasim, I.; Alalem, M.; Dweik, M.; Almasri, M. MEMS Based Impedance Biosensor for Rapid Detection of Low Concentrations of Foodborne Pathogens. In Proceedings of the IEEE 30th International Conference on Micro Electro Mechanical Systems (MEMS), Las Vegas, NV, USA, 22-26 January 2017; pp. 381-385.

69. Wang, R.; Lum, J.; Callaway, Z.; Lin, J.; Bottje, W.; Li, Y. A label-free impedance immunosensor using screen-printed interdigitated electrodes and magnetic nanobeads for the detection of E. coli O157: H7. Biosensors 2015, 5, 791-803. [CrossRef] [PubMed]

70. Gupta, A.; Bhardwaj, S.K.; Sharma, A.L.; Kim, K.-H.; Deep, A. Development of an advanced electrochemical biosensing platform for E. coli using hybrid metal-organic framework/polyaniline composite. Environ. Res. 2019, 171, 395-402. [CrossRef]

71. Wang, L.; Huang, F.; Cai, G.; Yao, L.; Zhang, H.; Lin, J. An electrochemical aptasensor using coaxial capillary with magnetic nanoparticle, urease catalysis and PCB electrode for rapid and sensitive detection of Escherichia coli O157: H7. Nanotheranostics 2017, 1, 403. [CrossRef]

72. Deshmukh, R.; Prusty, A.K.; Roy, U.; Bhand, S. A capacitive DNA sensor for sensitive detection of Escherichia coli O157: H7 in potable water based on the z3276 genetic marker: Fabrication and analytical performance. Analyst 2020, 145, 2267-2278. [CrossRef]

73. Cimafonte, M.; Fulgione, A.; Gaglione, R.; Papaianni, M.; Capparelli, R.; Arciello, A.; Bolletti Censi, S.; Borriello, G.; Velotta, R.; Della Ventura, B. Screen printed based impedimetric immunosensor for rapid detection of Escherichia coli in drinking water. Sensors 2020, 20, 274. [CrossRef]

74. Xu, S.; Zhang, Y.; Dong, K.; Wen, J.; Zheng, C.; Zhao, S. Electrochemical DNA biosensor based on graphene oxide-chitosan hybrid nanocomposites for detection of Escherichia coli O157: H7. Int. J. Electrochem. Sci 2017, 12, 3443-3458. [CrossRef]

75. Hassan, A.-R.; de la Escosura-Muñiz, A.; Merkoçi, A. Highly sensitive and rapid determination of Escherichia coli O157: H7 in minced beef and water using electrocatalytic gold nanoparticle tags. Biosens. Bioelectron. 2015, 67, 511-515. [CrossRef]

76. Ye, L.; Zhao, G.; Dou, W. An electrochemical immunoassay for Escherichia coli O157: H7 using double functionalized Au@ Pt/SiO2 nanocomposites and immune magnetic nanoparticles. Talanta 2018, 182, $354-362$. [CrossRef] 
77. Güner, A.; Çevik, E.; Şenel, M.; Alpsoy, L. An electrochemical immunosensor for sensitive detection of Escherichia coli O157: H7 by using chitosan, MWCNT, polypyrrole with gold nanoparticles hybrid sensing platform. Food Chem. 2017, 229, 358-365. [CrossRef] [PubMed]

78. Li, Y.; Deng, J.; Fang, L.; Yu, K.; Huang, H.; Jiang, L.; Liang, W.; Zheng, J. A novel electrochemical DNA biosensor based on HRP-mimicking hemin/G-quadruplex wrapped GOx nanocomposites as tag for detection of Escherichia coli O157: H7. Biosens. Bioelectron. 2015, 63, 1-6. [CrossRef]

79. Zhu, F.; Zhao, G.; Dou, W. A non-enzymatic electrochemical immunoassay for quantitative detection of Escherichia coli O157: H7 using Au@ Pt and graphene. Anal. Biochem. 2018, 559, 34-43. [CrossRef] [PubMed]

80. Abdalhai, M.H.; Fernandes, A.n.M.; Xia, X.; Musa, A.; Ji, J.; Sun, X. Electrochemical genosensor to detect pathogenic bacteria (Escherichia coli O157: H7) as applied in real food samples (fresh beef) to improve food safety and quality control. J. Agric. Food Chem. 2015, 63, 5017-5025. [CrossRef] [PubMed]

81. Xu, M.; Wang, R.; Li, Y. An electrochemical biosensor for rapid detection of E. coli O157: H7 with highly efficient bi-functional glucose oxidase-polydopamine nanocomposites and Prussian blue modified screen-printed interdigitated electrodes. Analyst 2016, 141, 5441-5449. [CrossRef]

82. Rajapaksha, R.; Hashim, U.; Uda, M.A.; Fernando, C.; De Silva, S. Target ssDNA detection of E. coli O157: H7 through electrical based DNA biosensor. Microsyst. Technol. 2017, 23, 5771-5780. [CrossRef]

83. Wang, Y.; Alocilja, E.C. Gold nanoparticle-labeled biosensor for rapid and sensitive detection of bacterial pathogens. J. Biol. Eng. 2015, 9, 16. [CrossRef]

84. Jaiswal, N.; Pandey, C.M.; Soni, A.; Tiwari, I.; Rosillo-Lopez, M.; Salzmann, C.G.; Malhotra, B.D.; Sumana, G. Electrochemical genosensor based on carboxylated graphene for detection of water-borne pathogen. Sens. Actuators B Chem. 2018, 275, 312-321. [CrossRef]

85. Das, R.; Chaterjee, B.; Kapil, A.; Sharma, T.K. Aptamer-NanoZyme mediated sensing platform for the rapid detection of Escherichia coli in fruit juice. Sens. Bio-Sens. Res. 2020, 27, 100313. [CrossRef]

86. Shaibani, P.M.; Etayash, H.; Jiang, K.; Sohrabi, A.; Hassanpourfard, M.; Naicker, S.; Sadrzadeh, M.; Thundat, T. Portable nanofiber-light addressable potentiometric sensor for rapid Escherichia coli detection in orange juice. ACS Sens. 2018, 3, 815-822. [CrossRef]

87. Grieshaber, D.; MacKenzie, R.; Vörös, J.; Reimhult, E. Electrochemical biosensors-sensor principles and architectures. Sensors 2008, 8, 1400-1458. [CrossRef] [PubMed]

88. Ivnitski, D.; Abdel-Hamid, I.; Atanasov, P.; Wilkins, E.; Stricker, S. Application of electrochemical biosensors for detection of food pathogenic bacteria. Electroanal. Int. J. Devoted Fundam. Pract. Asp. Electroanal. 2000, 12, 317-325. [CrossRef]

89. Zhou, Y.G.; Rees, N.V.; Compton, R.G. The electrochemical detection and characterization of silver nanoparticles in aqueous solution. Angew. Chem. Int. Ed. 2011, 50, 4219-4221. [CrossRef]

90. Lee, J.Y.; Kim, B.-K.; Kang, M.; Park, J.H. Label-free detection of single living bacteria via electrochemical collision event. Sci. Rep. 2016, 6, 30022. [CrossRef] [PubMed]

91. Couto, R.A.; Chen, L.; Kuss, S.; Compton, R.G. Detection of Escherichia coli bacteria by impact electrochemistry. Analyst 2018, 143, 4840-4843. [CrossRef] [PubMed]

(C) 2020 by the authors. Licensee MDPI, Basel, Switzerland. This article is an open access article distributed under the terms and conditions of the Creative Commons Attribution (CC BY) license (http://creativecommons.org/licenses/by/4.0/). 